\title{
Does Corporate Social Responsibility Determine the Stock Return of Indonesian Listed Firms?
}

\author{
Joseph Lie ${ }^{1}$, Yunieta Anny Nainggolan ${ }^{2}$ \\ $\left\{\right.$ Joseph_lie@sbm-itb.ac.id $\left.{ }^{1}\right\}$ \\ Institut Teknologi Bandung, Indonesia ${ }^{1,2}$
}

\begin{abstract}
As CSR becomes a company's obligation in Indonesia, question arises whether or not CSR will impact the return of listed companies. This research focus on testing CSR as a risk factor to help explain the stock return of listed companies in Indonesia by using KOMPAS100 companies. The methodology used in this research is Multi Linear Regression by regressing excess return (Ri-Rf) with 3 portfolio returns which are CSR Expense portfolio, Sri-Kehati Portfolio Return, and CSA Portfolio return. CSR Expense portfolio is formed by grouping the top 10\% highest and 10\% lowest CSR expense from the KOMPAS 100, the return of the portfolio is calculated by extracting HighCSR return from LowCSR as the researcher expects from previous studies that High CSR leads to lower return. The result of the regression indicates that CSR expense cannot explain the stock return significantly. However, the result is significant when using sustainability portfolio such as Sri-Kehati and CSA. This leads to conclusion that CSR is a significant risk factor that can be used to explain stock return, but in valuing the CSR of a company, CSR expense cannot be used as a single measurement, it has to include other aspect aside from expense alone.
\end{abstract}

Keywords: CSR, Portfolio, Return, Risk Factor, Multi Linear Regression.

\section{Introduction}

Corporate Social Responsibility (CSR) is a mandatory program that had to be done by companies that is according to Indonesian Law number 40 subsection 74 in 2007 about limited company, social responsibility, and the environment that is relevant to the company that runs the business and is affecting the natural resources and is not limited by its contribution that is also loaded on the financial report.

CSR is only good parties that is not bearing the expense of the CSR which means that a good news from CSR is not a good news for shareholder since they are the one that bear the cost [1]. There are studies that suspect CSR as only beneficial for managers that get good reputation from key stakeholder, however the cost used for CSR is not good for holder of share because they lost some of their retained earnings, this perspective was first popularized by Milton Friedman on its post said that 'The only responsibility of corporations is to make profits' (New York Times Magazine, 1970). However, there is another perspective of CSR from several researchers such as Edmans [2], Dimson, Karakas, and Li [3], Derwall, Guenster, Bauer and Koedijk [4], Flammer [5], Servaes and Tamayo [6], or Dowell, Hart and Yeung [7] where they stated that managers simply do CSR because these projects are perceived to have positive NPV and will increase shareholder wealth. Systematically, CSR means better image 
of a company, a better image will create better exposure creating bigger market thus leading to higher profitability business and in the end increase shareholder's wealth by increasing the stock price of the company, this assumption however has yet to be proven since the correlation of CSR and return is still unclear Ullmann [8].

This research is inspired by the Capital asset pricing model first developed by Sharpe and Lintner in 1964 and 1965 [9]. They suspect that the expected return of a stock can be calculated using a single variable called beta. However, in 1993 Eugene F. Fama and Kenneth R. French developed new variables to the existing CAPM model which will later be called the Three-Factor asset pricing model of Fama and French [10]. Fama and French model added additional variables of Small Minus Big (SMB) and High Minus Low (HML) to measure the size premium and value premium. Following the publish in 1993, Fama and French model had been challenged by other professional claiming that the three-factor model miss some important things, thus in 2014 Fama and French published a new model, The Five-Factor Asset Pricing Model [11]. The Five-Factor asset pricing model still uses the original 3 factors; SMB, HML and Market risk, but they added 2 additional factors to it which are profitability factor Robust Minus Weak (RMB) and investment factor Conservative Minus Aggressive (CMA). Learning from the research published by Fama and French [11], the researcher realise that they did not consider CSR as part of their formulation to explain return of stock, while on this era, brand image is something that is for sure affecting the stock price of a listed company and brand image can be correlated with CSR. Thus, triggering the researcher to study more about it.

The furthest studies related to this topic are done by several researchers in Indonesia that studies about the correlation of CSR to the corporate performance of listed company in Indonesia, there is however a study in China about Can CSR reduce stock price crash risk? Evidence from China's energy industry [12]. The study by $\mathrm{Wu} \& \mathrm{Hu}$ [12] focused on finding the evidence that CSR can reduce the risk of a stock price to crash, their study suggest that energy companies in China should invest more on their CSR to reduce their crash risk since good CSR send signal to investor that the management are not sending any bad news resulting in the investor to hold or buy the stock. Another study was also published by Ding, Ferreira, and Wongchoti [13] which suggest that value impact of CSR activities relies heavily on the industry-specific relative position of the firm [13]. Their study might not be directly related to this paper but their findings and methodology can be used in this paper as what both paper study about is the same, CSR on stock price. There is also one research from an undergraduate student from Indonesia that analyse the effect of CSR on the profitability of listed companies in mining industry in Indonesia [14], they conclude that there is no significant influence between profitability to CSR disclosure, it is however very limited to the scope of only mining industry.

The researcher tested CSR factor because CSR in the long run is an important factor for companies as explained by Caroline Flammer [15] in her study regarding environment awareness of shareholders. Dumitru et al. [16] also said in their study that CSR had impact on the stock return of a firm in Bucharest which led to the idea to test the factor in Indonesia.

\subsection{Research Question and Objective}

RQ1: How is the CSR performance of Indonesian listed firms during the period of 2015 to 2018?

RQ2: Is CSR another risk factor in CAPM that may determine the stock return of Indonesian listed firms? 
RO1: To find whether CSR performance may improve the CAPM to explain the stock return of Indonesian listed firms.

\section{Literature Review}

\subsection{Efficient Market Hypothesis (EMH)}

The concept of EMH has been evolving for years in finance industry, the concept explains that all asset's pricing in the market are 'efficient' meaning that it has reflect all the information available about the asset. This theory suggest that an investor cannot get extra return compared to others, or they can't defeat the market. This means that to get higher return would be to take higher risk asset [17]. This also means that no matter what model is used to calculate the excess return of an assets, the expected return of all model should be the same due to the same available information about the asset on the market [18]. EMH suggests that with all the available information of an asset, there could possibly be no abnormal return of a stock.

\subsection{Corporate Social Responsibility (CSR)}

The concern of CSR is to treat the stakeholders of the firm with ethic. Ethic means stakeholders getting treated in a manner that is accepted by civilized societies. Economic responsibility is included in Social. Stakeholders exist either within or outside a firm. Even the natural environment is considered as stakeholder. The bigger achievement of social responsibility is to achieve higher and higher standards of living, while keeping on preserving the profitability of the firm, for people both within and outside the firm [19]. So, CSR is moral behaviour of the company to their stakeholders. With numerous of understanding of CSR, there is not a single accepted term for it.

\subsection{Capital Asset Pricing Model (1964)}

Capital asset pricing model (CAPM) is a theory initially stated by Fama \& French in 1964 by Sharpe and Lintner [9] in their research Capital Asset Prices: A Theory of Market Equilibrium under Conditions of Risk where they suspect that the return of a stock can be predicted using a single measure called Beta. Beta is the variable to measure the sensitivity of a stock towards the market [10].

The CAPM model later evolved by Fama and French with added variables in 1993 and 2015. The risk-free rate refers to the government bond risk and the market premium refers to the expected return of market.

\subsection{Fama and French 3 Factor model Model (1993)}

In 1993, Fama and French published a study about additional variables that should be included in the original Sharpe CAPM model, those variables are Size and Book-To-Market equity. Fama and French result shows that these additional variables indeed show the return of a stock compared to its market.

The results are easy to summarize. Stocks and portfolios that mimic risk factors constructed by manager that is related to size and book to market value of equity have the capability to capture high common variation in terms of return, regardless of the time-series regression method. This can be proof that both size and book to market value of equity do have proxy for correlation to common risk factors in terms of stock returns, Even furthers, 
Fama and French [10] also examine the interception of three-factor regression which in the calculation include the excess market return and the similar returns for size and book to market equity value factors that are close to 0 . That, indicate that a market factor and the proxies developed by Fama and French [10] which includes size and book to market equity value can be concluded to have explained the cross-section of average stock returns in a good way [10].

\subsection{Fama and French Five-Factor Model (2015)}

On 2015, Fama and French published their research on yet another 2 additional variables to consider at Capital Asset Pricing Model after getting critics, The evidence from Novy Marx [20], Titman, Wei, and Xie [21], and others says that it is not a perfect model for excess because much of the variation is missed by the three factors. Triggered by the evidence and the valuation, French and Fama add profitability and investment factors to the three-factor model [11].

In the equation, RMW is the difference of the return from stock consisted in diversified portfolio with Robust for firm with high profitability and weak for firm with small profitability ,and CMA is the difference of the return from stock consisted in diversified portfolio with conservative for firm with low portion of retained earnings for expansion while aggressive is for firm with high portion of retained earnings for expansion [11]. Fama and French expect two interpretations of hypothesis of nun intercept. Looking up on Huberman and Kandel [22], is the first to say that the MVE tangency portfolio, which prices every available asset, combines the risk-free asset, the market portfolio, SMB, HML, RMW, and CMA. The proposed idea become more complicated as the equation for regression of a version of Merton's [23] framework where there is more than three not-specified state var leads to excess return that is not gotten by market factors. In this view, neither size nor book to market value nor operating profit nor investment are stated as state variables. What is not considered state variable mimicking portfolios are RMW, CMA, HML and SMB. Fama demonstrate that the variables are only portfolio consisted with diversified composite of disclosure to variable of unknown state. Supporting previous factors, the factor spans what is known as relevant multi factor efficient set. In this case, valuation role is to indicates the factors that will allow the researcher to get the glimpse of excess return effects from state variables without needing to know them [11].

\subsection{Sri-Kehati Index}

Sri-Kehati Index is an index listed in Indonesian stock exchange that is form by 25 companies that are categorized to have good sustainable and responsible investment (IDX.com). The index is form by IDX with collaboration from Yayasan Keanekaragaman Hayati Indonesia.

\subsection{Centre for Entrepreneurship, Change and Third Sector (CECT) Sustainability Award}

CECT is a study center under the university of Trisakti that is also a consultant for CSR in Jakarta. The goal of this study center is to award those who had comply to the ISO 26000 or the standard procedure for Corporate Social Responsibility (CECT official Website). CSA (CECT Sustainability Award) is the annual award given by CCET to companies that has been doing great on their CSR. 


\subsection{Development of Hypothesis}

Based on the literature review and previous study done by the researcher, the researcher wants to test whether or not CSR performance does impact return. With the understanding of $\mathrm{EMH}$, the researcher wanted to test if CSR information regarding a company can act as a risk factor that will add the risk of an asset, or in this case a stock, which will later explain the expected return of the stock. The $\mathrm{H} 0$ and $\mathrm{H} 1$ are declared as:

H0 $=$ CSR as a risk factor may not explain the stock return of Indonesian listed firms. H1 = CSR as a risk factor may explain the stock return of Indonesian listed firms.

\section{Research Method}

\subsection{Data Collection Method}

To collect the monthly return of market and monthly return of stocks, the researcher download the data of monthly market and stocks price in form of excel via Yahoo Finance, the return will then be calculated by using the equation of the current month price minus the previous month price divided by the previous month price using the Adjusted Close data from Yahoo Finance.

To collect the data of risk-free rate, $10 \mathrm{Y} \mathrm{Gov-Bond} \mathrm{monthly} \mathrm{data} \mathrm{is} \mathrm{used.} \mathrm{The} \mathrm{researcher}$ used data available from CNBC Indonesia website, the researcher considers using data from Indonesian Bond Pricing Agency (IBPA) website, however the data of 10Y Gov-Bond from 2017 is unavailable, there is only 1 -year data.

The CSR Expense data is collected though the annual report of the companies listed in KOMPAS100 Feb-July period. Some companies have their CSR Expense data in the dollar currency (usually Mining-Industry companies), the exchange rate used by the researcher is $\$ 1$ : IDR14000. The CSR Expense data that is collected from the companies ranging from 2015 to 2018, because majority of the 2019 data were still unavailable at the moment this research was done. The CSR Expense data will then be group, the $10 \%$ top and bottom of the group each year will be used to form another portfolio called LowCSR and HighCSR where their return will be calculated by averaging the return of stocks listed in the portfolio.

To form the portfolio for Sri-Kehati and CSA, the researcher collects the Sri-Kehati and CSA award winner data from their official website (Sri-Kehati and CSA website), and then choose companies that is consistently being awarded from 2015 to 2019 , the selected will then form a portfolio where the return of the portfolio will be based on the average of the stocks listed on the portfolio. The portfolios are form based on consistency due to different reason each. As for Sri-Kehati, because there is changes of 0 to 2 companies each year, the researcher expect that the difference will be insignificant even when using consistent portfolio, hence the reason. While for CSA, the rewarding of CSA is very different each year, on 2015 there are more than 20 companies awarded while on 2017 there is less than 10 companies awarded. The formatting reward each year is also different which makes it unfair if the portfolio is form solely on awarded companies each year, thus causing the researcher to form consistent portfolio After the portfolio is formed, the return of the portfolio will be calculated monthly using the same method as calculating stock's return mentioned above. 


\subsection{Data Analysis Method}

To analyse the data, researcher is going to use multiple linear regression method to understand if CSR can affect return with CAPM as the reference. The reason the model is using LowCSR minus HighCSR is because the researcher expect companies with lower CSR cost has higher risk compared to companies with higher CSR cost, this expectation is supported by the literature review by Lee and Faff at 2009 [24] where they stated that companies with high CSR performance have smaller market risk. Applying EMH, high CSR companies leads to lower return since it has lower risk while low CSR companies leads to higher return since it has higher risk. The multiple linear regression model is illustrated as follow.

$R_{i t}-R_{f t}=a_{1}+b_{1}\left(R_{m t}-R_{f t}\right)+c 1(($ LowCSR - HighCSR $) /($ Sri-Kehati Portfolio Return $) /(C S A$ Portfolio Return)) \pm eit

\subsection{Measurement of each variables}

- $\quad$ Ri: Monthly return of the selected stock.

- $\quad$ Rf: Monthly return of 10 Y government bond (data starts from June 2015, January to May 2015 is assumed to be same with June 2015 due to unavailability of data)

- $\quad \mathrm{Rm}$ : Monthly return of IHSG

- LowCSR: Excess of portfolio with the $10 \%$ lowest CSR expense.

- HighCSR: Excess of portfolio with the 10\% highest CSR expense.

- Sri-Kehati Portfolio Return: The average of stocks returns listed on the Sri-Kehati portfolio formed (explained in Data Collection Method)

- CSA Portfolio Return: The average of stocks returns listed on the CSA portfolio formed (explained in Data Collection Method)

- $\quad$ Eit: Error

\subsection{Test Statistic Procedure}

The Test Statistic Procedure used in this research will be using Stata. The data will be served in a comprehensive table in an excel, the data are consisted with Ri-Rf, Rm-Rf, LowCSR-HighCSR/Sri-Kehati Portfolio return/CSA Portfolio return, company code, and year. The data will then be run using standard multiple linear regression. To further understand the data, the researcher will then transform the data as a panel data by using company code as the panel ID and month as the time. After transforming the data into panel set, researcher will run the data using Fixed Effect Regression model and Random Effect model, the result of both will then be tested using Hausman test to validate which model is more proper. The result from the more proper model based on Hausman test will then be used for the analysis.

\section{Result and Discussion}

\subsection{Panel Result Discussion}

The researcher performs 3 correlation tests which are CSR Expense, Sri-Kehati Portfolio, and CECT Sustainability Award. Both Sri-Kehati and CSA are correlated positively, with CSR Expense as the only variable to be negatively correlated. All variables are tested with the $\mathrm{Ri}-\mathrm{Rf}$ and $\mathrm{Rm}-\mathrm{Rf}$ of the 61 companies mentioned before. 


\subsection{CSR Expense and Stock Return}

Table 1. The Linear Regression

\begin{tabular}{lccccc}
\hline Independent Variable & Coef. & Std. Err. & $\mathrm{P}>|\mathrm{t}|$ & \multicolumn{2}{c}{$95 \%$ Interval } \\
\hline Rm-Rf & 1.251238 & 0.0777189 & 0.000 & 1.098847 & 1.403628 \\
LowCSR-HighCSR & 0.0633246 & 0.412202 & 0.125 & -0.0174996 & 0.1441488 \\
Constanta & 0.007433 & 0.0025257 & 0.003 & 0.0024809 & 0.0123857 \\
\hline
\end{tabular}

With a total of 2867 number of observation, the $\mathrm{R}^{\wedge} 2$ of this model is $8.34 \%$, table 6 shows that linear regression result of LowCSR-HighCSR portfolio is not really significant in terms of reflecting the return of the stock since the $\mathrm{P}$ value is higher than $5 \%$ or $12.5 \%$, and $\mathrm{R}$ square is very low or only $8.34 \%$.

Using Hausman test to confirm the most appropriate test for this variable, the researcher found that Fixed effect is more suitable. So, the result for the fixed effect regression can be seen on table 2 .

Table 2. The fixed effect regression

\begin{tabular}{lccccc}
\hline Independent Variable & Coef. & Std. Err. & $\mathrm{P}>|\mathrm{t}|$ & \multicolumn{2}{c}{ 95\% Interval } \\
\hline Rm-Rf & 1.251238 & 0.777137 & 0.000 & 1.098856 & 1.40362 \\
LowCSR-HighCSR & 0.0633246 & 0.412174 & 0.125 & -0.017494 & 0.1441442 \\
Constanta & 0.0074333 & 0.0025255 & 0.003 & 0.0024812 & 0.0123854 \\
\hline
\end{tabular}

The result from above confirms that LowCSR-HighCSR portfolio indeed is not a significant variable to explain return of the 61 stocks. Because the factor is not a significant factor, the previous CAPM model still remains as the significant one.

\subsection{Alternative Test using Sri-Kehati Portfolio}

Table 3. The linear regression for Sri-Kehati Portfolio

\begin{tabular}{lccccc}
\hline Independent Variable & Coef. & Std. Err. & P > |t & \multicolumn{2}{c}{$95 \%$ Interval } \\
\hline Rm-Rf & 0.3028243 & 0.1750267 & 0.084 & -0.0403 & 0.6460 \\
Sri-Kehati Portfolio & 0.7051531 & 0.1197044 & 0.000 & 0.4704 & 0.93987 \\
Constanta & 0.0000991 & 0.0027764 & 0.972 & -0.00535 & 0.00554 \\
\hline
\end{tabular}

Table 3 shows that Sri-Kehati portfolio return is correlated with the return of the 61 companies used before since its $\mathrm{P}$ value is lower than 5\%. The positive coefficient also shows that they are positively correlated with expectation that for every increase of 1 percent in SriKehati Portfolio return, the return Ri-Rf may increase by 0.7 .

Hausman test result shows that Sri-Kehati Portfolio is better explained by Random effect regression rather than fixed effect. The result is shown table 4.

Table 4. Result shows that Sri-Kehati Portfolio is better explained by Random effect regression rather than fixed effect

\begin{tabular}{lccccc}
\hline Independent Variable & Coef. & Std. Err. & P $>|t|$ & \multicolumn{2}{c}{$95 \%$ Interval } \\
\hline Rm-Rf & 0.3028243 & 0.1749938 & 0.084 & -0.401572 & 0.6458059
\end{tabular}




\begin{tabular}{llllll} 
Sri-Kehati Portfolio & 0.7051531 & 0.1196819 & 0.000 & 0.4705808 & 0.9397253 \\
Constanta & 0.0000991 & 0.002796 & 0.972 & -0.00538 & 0.0055791 \\
\hline
\end{tabular}

Similar with Linear regression, the random effect regression shows that the return of SriKehati portfolio can significantly explain the return of the 61 companies. The regression result indicates that the Constanta is insignificant in the model which leads to the EMH theory that suggest there is no abnormal return or return unexplained by risk factor (Constanta equal 0 ). This model supports the theory of EMH since the Constanta is not significant in explaining the expected return

\subsection{Alternative Test using CSA Portfolio}

Table 5. The Linear regression for CSA Portfolio

\begin{tabular}{lccccc}
\hline Independent Variable & Coef. & Std. Err. & $\mathrm{P}>|\mathrm{t}|$ & \multicolumn{2}{c}{$95 \%$ Interval } \\
\hline Rm-Rf & 0.7876 & 0.13119 & 0.000 & 0.53038 & 1.0448 \\
CSA Portfolio & 0.3478 & 0.08364 & 0.000 & 0.18381 & 0.5118 \\
Constanta & 0.0035 & 0.0027 & 0.182 & -0.0016 & 0.0087 \\
\hline
\end{tabular}

Table 5 shows that CSA Portfolio Return is a very significant variable to explain Ri-Rf of the 61 companies since the $\mathrm{P}$ value is very low. The positive coefficient also shows that the correlation of CSA Portfolio with Ri-Rm is positive with expectation of every 1 percent increase in CSA Portfolio return will increase the Ri-Rf by 0.3478 .

Test result shows that CSA Portfolio is better explained by Random effect regression rather than fixed effect. The result shown table 6.

Table 6. Test result shows that CSA Portfolio is better explained by Random effect regression rather than fixed effect

\begin{tabular}{lccccc}
\hline Independent Variable & Coef. & Std. Err. & $\mathrm{P}>|\mathrm{t}|$ & \multicolumn{2}{c}{$95 \%$ Interval } \\
\hline Rm-Rf & 0.7876 & 0.13117 & 0.000 & 0.53052 & 1.0447 \\
CSA Portfolio & 0.3478 & 0.08363 & 0.000 & 0.18389 & 0.5117 \\
Constanta & 0.00355 & 0.00267 & 0.184 & -0.00168 & 0.00878 \\
\hline
\end{tabular}

Similar with Linear regression, the random effect regression shows that the return of CSA portfolio can significantly explain the return of the 61 companies. This model regression result shows that the Constanta is insignificant in the model to explain return, means that there is no abnormal return on this model. This model is also supporting the EMH theory where the Constanta equal to 0 .

\subsection{CSR as a Risk Factor Discussion}

To answer the research question of can CSR as a risk factor explain the return of stocks listed in Indonesia, using available test result the researcher suggest that CSR can as a risk factor explain the return of stocks listed in Indonesia, it is however very important to understand that CSR cannot be solely quantified using the Expense (money spent on the CSR) only, rather we can use the portfolio of good CSR companies formed by legitimate organization such as Sri-Kehati and CECT to explain the market return. 
Both CSA and Sri-Kehati regression results shows on their $95 \%$ confidence interval that their coefficient of the CSR risk factor is positive, this could be an indication which shows that the correlation coefficient of CSR and stock return is expected to be positive at $95 \%$ confidence interval

The result of those regressions could lead to an understanding that the higher the CSR risk get, the higher the expected return of investors gets. This understanding is based on the positive coefficients of the regression which tells that increase in risk factor will increase in expected return and vice versa

The significant result from 2 portfolios test indicates that CSR performance can indeed be used as a risk factor that can explain the expected return of stocks in Indonesia from 20152018 period.

Sri-Kehati and CSA portfolio model also shows that the Constanta in their model is insignificant in explaining the expected return which means that both this model supports the EMH theory where there is no abnormal return in the model.

Practically, the overall result of the tests implies that CSR is found to be a risk factor that can explain the expected return of stock listed in Indonesia from 2015 to 2018 period.

\section{Conclusion}

This paper examines the correlation of CSR and stock return using 3 variables, CSR expense, Sri-Kehati Portfolio return and CSA Portfolio return. The Panel tests result indicates that there is no significant influence of CSR expense to the stocks' return while there is significant influence of both Sri-Kehati and CSA portfolio to the stocks' return. Using 95\% confidence interval, it is confirmed by Sri-Kehati and CSA portfolio test that the correlation of those portfolio returns with the stocks' return is positive. This study implies that CSR can be a risk factor to determine stocks' expected return in Indonesia. However, it is important to note that to measure CSR it is not good to only use expense as the only quantification as it fails to significantly explain the stocks' return, because CSR expense cannot capture the risk asserted in the CSR risk factor. Instead, we can use the portfolio formed by legitimate organization such as Sri-Kehati and CSA to be used as a factor to explain stock return.

\section{References}

[1] P. Krüger, "Corporate goodness and shareholder wealth," J. financ. econ., vol. 115, no. 2, pp. 304-329, 2015.

[2] A. Edmans, "Does the stock market fully value intangibles? Employee satisfaction and equity prices," J. financ. econ., vol. 101, no. 3, pp. 621-640, 2011.

[3] X. Dimson, E., Karakas, O., Li, "Active ownership," Unpubl. Work. Pap. London Bus. Sch. Bost. Coll. Temple Univ., 2013.

[4] J. Derwall, N. Guenster, R. Bauer, and K. Koedijk, "The eco-efficiency premium puzzle," Financ. Anal. J., vol. 61, no. 2, pp. 51-63, 2005.

[5] C. Flammer, "Corporate social responsibility and shareholder reaction: The environmental awareness of investors," Acad. Manag. J., vol. 56, no. 3, pp. 758-781, 2013.

[6] H. Servaes and A. Tamayo, "The impact of corporate social responsibility on firm value: The role of customer awareness," Manage. Sci., vol. 59, no. 5, pp. 1045-1061, 2013.

[7] G. Dowell, S. Hart, and B. Yeung, "Do corporate global environmental standards create or destroy market value?," Manage. Sci., vol. 46, no. 8, pp. 1059-1074, 2000.

[8] A. A. Ullmann, "Data in search of a theory: A critical examination of the relationships among 
social performance, social disclosure, and economic performance of US firms," Acad. Manag. Rev., vol. 10, no. 3, pp. 540-557, 1985.

[9] W. F. Sharpe, "Capital asset prices: A theory of market equilibrium under conditions of risk," $J$. Finance, vol. 19, no. 3, pp. 425-442, 1964.

[10] E. F. Fama and K. R. French, "Common risk factors in the returns on stocks and bonds," J., 1993.

[11] K. R. Fama, E. F., \& French, “A five-factor asset pricing model,” J. financ. econ., vol. 116, no. 1, pp. 1-22, 2015.

[12] C.-M. Wu and J.-L. Hu, "Can CSR reduce stock price crash risk? Evidence from China's energy industry," Energy Policy, vol. 128, pp. 505-518, 2019.

[13] D. K. Ding, C. Ferreira, and U. Wongchoti, "Does it pay to outclass? Corporate social responsibility and its impact on firm value," Corp. Soc. Responsib. Its Impact Firm Value (August 21, 2014), 2014.

[14] R. Asmeri, T. Alvionita, and A. Gunardi, "CSR disclosures in the mining industry: Empirical evidence from listed mining firms in Indonesia," Indones. J. Sustain. Account. Manag., vol. 1, no. 1, pp. 16-22, 2017.

[15] C. Flammer, "Corporate social responsibility and stock prices: The environmental awareness of shareholders," in fourth annual research conference, Yale University, 2012, vol. 16.

[16] A. Dumitru, I. Lema-Blanco, R. Kunze, R. Kemp, J. Wittmayer, A. Haxeltine, and S. Cozan, "Social learning in social innovation initiatives: Learning about systemic relations and strategies for transformative change," TRANSIT Br., vol. 4, pp. 1-2, 2017.

[17] A. Gabriela ğiĠan, "The efficient market hypothesis: Review of specialized literature and empirical research," Procedia Econ. Financ., vol. 32, pp. 442-449, 2015.

[18] B. Fakhry, "A literature review of the efficient market hypothesis," Turkish Econ. Rev., vol. 3, no. 3, pp. 431-442, 2016.

[19] M. Hopkins, "Corporate social responsibility: an issues paper," Available SSRN 908181, 2004.

[20] R. Novy-Marx, "The other side of value: The gross profitability premium," J. financ. econ., vol. 108, no. 1, pp. 1-28, 2013.

[21] S. Titman, K.-C. Wei, and F. Xie, "Capital investments and stock returns," National Bureau of Economic Research, 2003.

[22] G. Huberman and S. Kandel, "Mean-variance spanning," J. Finance, vol. 42, no. 4, pp. 873888, 1987.

[23] R. C. Merton, “An intertemporal capital asset pricing model,” Econom. J. Econom. Soc., pp. 867-887, 1973.

[24] D. D. Lee and R. W. Faff, "Corporate sustainability performance and idiosyncratic risk: A global perspective," Financ. Rev., vol. 44, no. 2, pp. 213-237, 2009. 